Summer 2015

\title{
The Role of Central Banks in Global Austerity
}

Timothy A. Canova

Nova Southeastern University - Shepard Broad Law Center, canovat@nsu.law.nova.edu

Follow this and additional works at: https://www.repository.law.indiana.edu/ijgls

Part of the Banking and Finance Law Commons, and the International Law Commons

\section{Recommended Citation}

Canova, Timothy A. (2015) "The Role of Central Banks in Global Austerity," Indiana Journal of Global Legal Studies: Vol. 22 : Iss. 2 , Article 12.

Available at: https://www.repository.law.indiana.edu/ijgls/vol22/iss2/12

This Symposium is brought to you for free and open access by the Law School Journals at Digital Repository @ Maurer Law. It has been accepted for inclusion in Indiana Journal of Global Legal Studies by an authorized editor of Digital Repository @ Maurer Law. For more information, please contact rvaughan@indiana.edu.

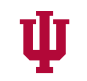

JEROME HALL LAW LIBRARY

$$
\text { INDIANA UNIVERSITY }
$$

Maurer School of Law
Bloomington 


\title{
The Role of Central Banks in Global Austerity
}

\author{
TIMOTHY A. CANOVA ${ }^{*}$
}

The literature on austerity, by scholars and policymakers alike, has largely downplayed the important role of central banks in designing and implementing global austerity both before and since the 2008 financial crisis. This article considers how and why the world's leading central banks display an inherent bias toward austerity. As central banks have become increasingly influenced and even captured by large private banks and financial institutions, they have pursued policy agendas that favor those same private interests. The structure of the U.S. Federal Reserve suggests a central bank that has been captured by design and is rife with inherent conflicts of interest in its governance, regulatory, and monetary policy functions. These conflicts are often overlooked because of the myth of central bank independence, which has rested on truncated empirical studies and flawed readings of economic history. Yet, the myth has legitimized the Federal Reserve's policy agenda-particularly beginning in the 1980s when Alan Greenspan became chair of the Federal Reserve-when deregulation, liberalization, and privatization came to serve the private interests of Wall Street banks while creating a boomand-bust bubble economy. The austerity bias of central banks was also revealed in both the academic work and monetary policy approach of Ben Bernanke, who succeeded Greenspan as Federal Reserve chairman just ahead of the 2008 financial collapse. Not only was the Federal Reserve's response to crisis a reflection of the domination of Wall Street interests, it also revealed a complete misreading of the lessons from the Great Depression by Bernanke and other mainstream economists. The result has been a flawed "trickle-down" response to the financial crisis, as the Federal Reserve and other leading central banks have provided massive subsidies to financial institutions and markets while relegating other sectors of the economy and society to the pains of austerity. A more balanced economic approach will require reform of central bank governance to include representatives of a wider range of social interests in monetary policymaking.

Indiana Journal of Global Legal Studies Vol. 22 \#2 (Summer 2015)

(C) Indiana University Maurer School of Law 


\section{INTRODUCTION}

William McChesney Martin, the longest-serving Federal Reserve Board chairman from 1951 to 1970 , remarked that the job of central bankers is to take away the punch bowl just as the party gets going. ${ }^{1}$ Well before the 2008 financial crisis, central bankers were the "gatekeepers of growth," effectively deciding on both the degree and timing of monetary and even fiscal austerity. ${ }^{2}$ The Federal Reserve was intended to "lean against the wind," preventing inflation by raising interest rates at the first signs that the economy may be starting to overheat. According to conventional wisdom, Congress, the White House, and appointed officials at the Department of the Treasury are not well qualified to make these decisions because of their short-term incentives for reelection and continuity in office. It is assumed that politicians are much more likely to spike the punch bowl when the party is reaching its peak. This would arguably result in a big hangover: higher inflation and an unsustainable economic expansion would be followed by recession and even higher unemployment rates.

The theory of central bank independence assumes that central bankers are in the best position to decide when to take away the punch bowl because they are disinterested, socially neutral, and not favoring any one segment of the market or of society over others. The expansion of central bank powers since 2008 has raised doubts about these assumptions.

This article considers the relationship between central bank independence and austerity. The governance structure of the U.S. Federal Reserve System (the Fed), the world's most powerful central bank, is dominated by private banking interests that own the shares of the regional Federal Reserve Banks (FRBs or Fed Banks) which in turn dominate the Federal Open Market Committee (FOMC), the Fed's monetary policy-making arm. This structure suggests that central bank independence is a myth, a cover for the capture of central banks by private banking interests. What we see is pseudo-independence, a false independence. Part I considers the captured Fed as a failure of the rule of law that harms those lacking genuine representation on its key

* Professor of Law and Public Finance, Nova Southeastern University, Shepard Broad College of Law.

1. William McChesney Martin, Jr., Chairman, Bd. Governors Fed. Res. Sys., Address before the New York Group of the Investment Bankers Association of America (Oct. 19, 1955), available at https://fraser.stlouisfed.org/docs/historical/martin/martin55_1019.pdf.

2. See Sylvia MaXfield, GatekeEPERs of GrowTH: The INTERnational Political ECONOMY of CENTRAL BANKING IN DEVELOPING COUNTRIES 37-44 (1997) (discussing the role of central bank independence as a marker for international creditworthiness). 
boards and committees and is biased toward an austerity agenda. Although central bank governance may be increasingly independent of politics, it is not independent of the private banking and financial interests that central banks are charged with regulating, supervising, and supporting. The crisis heightened the gulf between what the pseudo-independent central bank promises and what it delivers in reality.

Part II considers the central banking agenda during the 1987-2006 period when Alan Greenspan chaired the Federal Reserve Board. Significant reforms occurred during this period, including the liberalization of finance and trade, deregulation and de-supervision of mortgage lenders and Wall Street banks, and the emergence of a casino economy. Greenspan and the pseudo-independent Fed played a decisive role in shifting the U.S. economy from widely shared prosperity to a winner-take-all society.

Greenspan left the Federal Reserve just as the housing and mortgage markets turned soft and declined. President George W. Bush appointed his top White House economic advisor Ben Bernanke to replace Greenspan as Fed chairman. Bernanke, a Princeton economist who claimed a reputation as an authority on the Great Depression of the 1930s, soon expanded the Fed's lending and asset purchase powers well beyond its traditional boundaries to allocation decisions that effectively picked winners and losers in the financial marketplace. This expansion raised questions about the Fed's purported social neutrality and the justifications for its political independence from the representative branches of government. Not only was the Fed's response a reflection of the domination of private financial interests, the response also revealed a complete misreading of the Great Depression by Bernanke and other mainstream economists. Part III analyzes the flaws in Bernanke's understanding of the Great Depression; Part IV analyzes flaws in his trickle-down monetary policy as Fed chairman, which has contributed to austerity. The arguments for austerity are tenuous and the evidence is thin. As Mark Blyth points out, austerity policies worsened the Great Depression in the 1930s and have more recently worsened the economic depression in Greece. Governments have been punished for the enormous increases in shaky private debt, made possible by central banks and private banking clienteles. ${ }^{3}$ When the markets crashed, much of the private "toxic" debt was simply rechristened as government debt, and governments were placed in austerity programs under central bank supervision.

3. Mark Blyth, Austerity: The History of a Dangerous Idea 47 (2013). 
This article concludes by offering a review of the forgotten lessons of the Great Depression, the futility of austerity, and the need for a "bottom-up" recovery and ongoing economic strategy.

\section{CENTRAL BANK INDEPENDENCE AND THE AUSTERITY BIAS}

Austerity comes in many forms. Central banks are usually not far from the surface when tracing austerity back to its origin. Central banks often tighten the money supply, raise interest rates at the first whiff of inflation, and raise interest rates to protect or prop up their currency. These examples of monetary austerity are associated with rising unemployment and interest costs coupled with falling incomes and declining tax revenues for governments at all levels-federal, state, and local. These effects, in turn, place pressure on governments to impose fiscal austerity in the form of spending cuts, tax hikes and user fees, and the privatizations of state-owned assets and services usually at bargain basement fire-sale prices. Rising public debt levels, and the adverse reaction of financial markets, put pressure on governments to turn to fiscal austerity, which is then often imposed as loan conditions by central banks, such as the European Central Bank (ECB) and the International Monetary Fund (IMF), effectively a global central bank.

The crisis of 2007-2009 revealed an ever-widening range of central bank policies contributing to austerity. ${ }^{4}$ The U.S. Federal Reserve and foreign central banks played key roles in creating huge private debt bubbles built on unsustainable asset price inflations through the combination of easy money policies and lax supervision of lending standards by central banks. When the asset bubbles burst, governments at all levels faced falling tax revenues and rising cleanup costs, from bank bailouts to unemployment compensation. Severe fiscal austerity measures were often imposed on state and local governments across the United States and on foreign countries, such as the so-called PIGS of the Eurozone, including Portugal, Italy, Ireland, Greece, and Spain. Pseudo-independent central bankers created a "moral hazard" by propping up the big banks that had financed the bubble. ${ }^{5}$ Through austerity, the losses would be shifted to taxpayers, consumers, workers,

4. See Timothy A. Canova, The New Global Dis/Order in Central Banking and Public Finance, in HANDBOOK ON POLITICAL ECONOMY AND LAW (John D. Haskell \& Ugo Mattei eds., forthcoming 2015) (manuscript at 9-19) (on file with author) (describing the policy objectives, tools, and responses of the Federal Reserve to the 2007-2008 Financial Crisis).

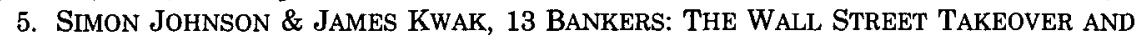
THE NEXT FINANCIAL MELTDOWN 29 (2010). This has also been referred to as the "Greenspan put"- "the idea that if trouble occurred in the markets, the Fed would come to their rescue." Id. at 101. 
and the unemployed. And through austerity, new profit opportunities would be created for big banks and hedge funds. Indeed, central banks led by the Federal Reserve responded to the crisis in ways that intensified austerity for large vulnerable segments of the population, while propping up and subsidizing elite private financial interests.

The most visible face of the Federal Reserve System is the Fed's Board of Governors in Washington, D.C. The Board consists of seven governors appointed by the U.S. president and confirmed by the Senate. Although this process provides a semblance of public accountability, Fed governors serve fourteen-year terms, longer than three presidential administrations and longer than any other federal official. In addition, the terms are staggered so that the term of each governor expires every two years, thereby limiting the number of appointments a president can make in a single term. ${ }^{6}$ The Fed does not depend on congressional appropriations, but instead funds itself from the interest it earns on its holdings of Treasury securities. It is exempt from numerous procedural requirements of administrative law that apply good governance norms to most federal agencies. ${ }^{7}$ Finally, monetary policy is not subject to judicial review. As Professor Alfred Aman concludes, "Compared to most other regulatory agencies, even independent commissions, the Fed is remarkably free from direct political control."8

Over the years, some have attempted to reduce the influence of private bankers by making the Board of Governors more accountable to the representative branches of government. For instance, in 1962 President John F. Kennedy proposed revising the terms of the officers and members of the Federal Reserve Board of Governors to synchronize the terms of the Fed chairman and the U.S. president. This revision would have allowed a new president "to nominate a chairman of his choice for a term of four years conterminous with his own."9 However,

6. In addition, Fed governors are removable by the President only for cause. Alfred C. Aman, Jr., Bargaining for Justice: An Examination of the Use and Limits of Conditions by the Federal Reserve Board, 74 IOWA L. REV. 837, 850 (1989).

7. Freedom of Information Act, 5 U.S.C. $\$ 552(b)(5)$ (2009) (providing exemption for certain Federal Reserve directives and information that is part of its deliberative process); Federal Advisory Committee Act, 5 U.S.C. $\S 4$ (b)(1)-(2) (2010) (exempting any advisory committee of the Federal Reserve System and the Central Intelligence Agency from provisions of the Federal Advisory Committee Act).

8. Aman, supra note 6 , at 850 .

9. John F. Kennedy, Message to the Congress Presenting the President's First Economic Report, 16 PUB. PAPERS 54-55 (Jan. 22, 1962); see also DoNALD GiBSON, BATtling Wall Street: The KenNedy PResidency 30 (1994) (discussing the Commission on Money and Credit's 1961 report; "[Kennedy] did quickly accept one of its recommendations, which would allow the incoming president to designate a chairman who served the same four years as the president."). 
the proposal was not acted on before Kennedy's death, and has not been raised by any of his successors.

The Fed's monetary policy decisions are centralized in its Federal Open Market Committee (FOMC), which consists of the Board of Governors and the presidents of the twelve regional Federal Reserve Banks. ${ }^{10}$ While all twelve regional Fed presidents take part in FOMC deliberations, only five can vote on policy decisions, while the remaining seven serve in an ex officio capacity. The president of the New York Fed always votes in FOMC meetings, while the other eleven regional Fed presidents vote on a rotating basis. Therefore, selecting regional Fed presidents is crucial to the formulation of monetary policy.

The boards of directors of the regional Fed banks are effectively selected by the private commercial banks that are members of the Federal Reserve System and own shares of those regional Fed banks. These boards, in turn, select the presidents of the regional Fed Banks that sit on the Open Market Committee. ${ }^{11}$ This process presents several inherent conflicts of interest. For instance, Jamie Dimon, the chief executive of JP Morgan Chase, was on the N.Y. Federal Reserve Bank board (the N.Y. Fed) at a time when his bank received billions of dollars in emergency loans and significant regulatory relief from the Federal Reserve. ${ }^{12}$

The Dodd-Frank Wall Street Reform and Consumer Protection Act of 2010 (the Dodd-Frank Act), which was the Obama administration's main legislative response to the crisis, purported to reform the governance of the boards of the regional Fed Banks to dilute the dominating influence of private banking shareholders. However, the

10. Allan H. MELTZER, A History of the Federal Reserve: Volume 1: 1913-1951, 430 (2003) (describing the creation and authority of the FOMC).

11. See Federal Reserve Act, 12 U.S.C. $\S 263$ (describing the FOMC's creation, membership, and regulations governing open-market transactions); id. $\S 304$ (outlining selection of Class A and B directors); id. $\S 305$ (outlining selection of Class $\mathrm{C}$ directors); see also Aman, supra note 6, at 848 n.49.

12. See Press Release, Senator Bernie Sanders, GAO Finds Serious Conflicts at the Fed (Oct. 19, 2011), http:/www.sanders.senate.gov/newsroom/press-releases/gao-finds-seriousconflicts-at-the-fed. According to U.S. Senator Bernie Sanders, while Dimon was on the board of the N.Y. Fed, JP Morgan Chase "received emergency loans from the Fed and was used by the Fed as a clearing bank for the Fed's emergency lending programs. In 2008, the Fed provided JP Morgan Chase with $\$ 29$ billion in financing to acquire Bear Stearns. At the time, Dimon persuaded the Fed to provide JP Morgan Chase with an 18-month exemption from risk-based leverage and capital requirements. He also convinced the Fed to take risky mortgage-related assets off of Bear Stearns balance sheet before JP Morgan Chase acquired this troubled investment bank." Id. 
changes were completely cosmetic. ${ }^{13}$ The same dynamic that existed before the crisis still exists today: the regional Fed boards and the Open Market Committee are dominated by banking and big business interests, while effectively excluding all other public constituencies from any genuine representation. Main Street groups, from small business owners and student debtors to average workers and consumers, are often negatively affected by the Fed's policies, yet they lack any voice or seat at the table. ${ }^{14}$

The Dodd-Frank Act also included a provision requiring the U.S. Government Accountability Office (GAO) to conduct an audit of the governance of the regional Fed Banks, including an examination of the system of appointing directors and any actual or potential conflicts of interest. $^{15}$ A year later, the GAO issued its report finding serious conflicts of interest. For instance, in 2008, Stephen Friedman, the chairman of the N.Y. Fed, was also on the board of directors of Goldman Sachs and owned Goldman stock. At this time, the N.Y. Fed was approving Goldman's application to become a bank holding company to obtain access to the Fed's low-interest loans. ${ }^{16}$ Meanwhile, Friedman chaired the search for a new president of the N.Y. Fed that resulted in the selection of William Dudley, who had recently been a partner and managing director at Goldman and served for a decade as its chief U.S. economist. ${ }^{17}$ Moreover, in September 2010, Reuters published a special investigative report of the Federal Reserve's selective disclosure of sensitive information about monetary policy to its favored clientele in the private financial sector. These backroom exchanges are among the many quid pro quos in a system of opaque subsidies and reveal part of a bigger problem of private financial influence over economic decision making. ${ }^{18}$

13. See Canova, supra note 4 (manuscript at 5-6) (providing a more complete discussion of the significance of the changes in Class A, B, and C directors of the regional Federal Reserve Banks).

14. See Simon Johnson, An Institutional Flaw at the Heart of the Federal Reserve, N.Y. TIMES, June 14, 2012, http://economix.blogs.nytimes.com/2012/06/14/an-institutional-flawat-the-heart-of-the-federal-reserve/.

15. Dodd-Frank Wall Street Reform and Consumer Protection Act of 2010, H.R. 4173, 111th Cong., $\S 1109$ (b)(1)(B)(i), (ii), (iv) (2010) (current version at 12 U.S.C. $\S 5611-14$ (2010)).

16. Sanders, supra note 12.

17. Press Release, Fed. Reserve Bank of N.Y., New York Fed Names William C. Dudley President (Jan. 27, 2009), http://www.ny.frb.org/newsevents/news/aboutthefed/2009/oa09 0127.html.

18. Kristina Cooke et al., Special Report: The Ties That Bind at the Federal Reserve, REUTERS (Sept. 30, 2010, 4:19 PM), http://www.reuters.com/article/2010/09/30/us-usa-fedidUSTRE68S01020100930. 
These conflicts of interest also raise questions about the rigor and impartiality of the regulatory supervision and oversight of the world's biggest banks. For example, in 2009, the N.Y. Fed commissioned a secret internal investigation of itself conducted by a Columbia University finance professor. This investigation revealed "a culture of suppression [that] discouraged regulatory staffers from voicing worries about the banks they supervised." 19 The review recommended various reforms for the N.Y. Fed to encourage "critical dialogue and continuous questioning." Yet, four years later its culture was still in question when one of its former bank examiners, Carmen Segarra, filed a lawsuit alleging that the N.Y. Fed had interfered with her oversight of Goldman Sachs. ${ }^{20}$ Segarra's lawsuit could not be easily ignored since she had secretly recorded audio of some forty-six hours of meetings and conversations with her colleagues and superiors. Some of the most damning recordings aired on "This American Life," a program on the WBEZ-Chicago public radio station. ${ }^{21}$

Although Wall Street influence and conflicts of interest are now increasingly seen as problems in terms of the Fed's regulatory responsibilities, there has been less attention paid to their impact on Federal Reserve monetary policies. This anomaly stems from the broad consensus of central bank independence. ${ }^{22}$ The research departments of central banks have produced a mountain of paid literature purporting to prove a strong correlation between central banks' independence and low inflation rates. ${ }^{23}$ However, the research demonstrates a consistent pattern of selective presentation of evidence, a myopic focus on limited

19. Pedro Nicolaci da Costa, N.Y. Fed Staff Afraid to Speak Up, Secret Review Found, Wall St. J. Real Time ECON. Blog, (Sept. 26, 2014, 3:17 PM), http://blogs.wsj.com/ economics/2014/09/26/n-y-fed-staff-afraid-to-speak-up-secret-review-found.

20. See Jessica Silver-Greenberg et al., Rising Scrutiny as Banks Hire From the Fed, N.Y. TIMES, Nov. 20, 2014, at A1 (covering the emergence of the Segarra allegation); Peter Eavis, New York Fed Is Criticized on Oversight, N.Y. TIMES, Nov. 22, 2014, at B1 (describing the oversight Senate hearing).

21. See Jake Bernstein, Inside the New York Fed: Secret Recordings and a Culture Clash, ProPublica (Sept. 6, 2014, 5:00 AM), http://www.propublica.org/article/carmensegarras-secret-recordings-from-inside-new-york-fed (describing the audio release).

22. See Ben S. Bernanke, Chairman, Bd. of Governors of Fed. Reserve Sys., Central Bank Independence, Transparency, and Accountability, Remarks at the Institute for Monetary and Economic Studies International Conference 2 (May 26, 2010), available at http://www.federalreserve.gov/newsevents/speech/bernanke20100525a.pdf (explaining the case for Central Bank Independence).

23. Agustín Carstens \& Luis I. Jácome H., Latin American Central Bank Reform: Progress and Challenges 15 tbl.6 (Int'l Monetary Fund, Working Paper No. 05/114, 2005) (comparing changes in macroeconomic indicators from the 1980 s to 2003). 
variables and limited time periods, and flawed readings of history. ${ }^{24}$ Virtually none of these studies consider data from the 1920 s to the mid$1950 \mathrm{~s}$, thereby avoiding the 1929 stock market crash, the financial panics of the early 1930s, the Great Depression, the economic boom of the $1940 \mathrm{~s}$, and the more recent data from the 2008 financial collapse. ${ }^{25}$ Most studies confine their analyses to the 1980 s and 1990 s while overlooking any and all non-monetary explanations for variations in inflation rates. In addition to the truncated period and focus of analysis, these studies share a fixation on one variable-the rate of increase in a rather flawed consumer price index-while ignoring all other kinds of price inflations, most notably hyperinflations of asset prices, seen often only in hindsight as unsustainable bubbles.

One study coauthored by Larry Summers, a main architect of financial deregulation as undersecretary of Treasury in the late 1990s, found no correlation between central bank independence and higher economic growth rates precisely because Summers did not consider any data prior to 1955 and focused primarily on the period from 1973 to 1988. ${ }^{26}$ However, if U.S. economic growth rates in the $1940 \mathrm{~s}$ are compared with growth rates in more recent years, the conclusions are much different. In fact, U.S. gross national product (GNP) grew at an average rate of about 5.4 percent a year during the 1940 s when the Federal Reserve was de facto politically directed,27 compared with average annual GNP growth of about 2.4 percent from 1973 to 1987 when the Federal Reserve was far less accountable. ${ }^{28}$ Therefore, real economic growth rates were more than twice as high when the central

24. Timothy A. Canova, Central Bank Independence as Agency Capture: A Review of the Empirical Literature, 30 BANKING \& FIN. SERV. POL'Y REP. 11, 14-16 (2011); see Richard A. Werner, What Accession Countries Need to Know About the ECB: A Comparative Analysis of the Independence of the ECB, the Bundesbank and the Reichsbank, 6 INT'L FIN. REV. 99 (2006).

25. In this way, they mimic the risk management models used by big banks and credit rating agencies in the past decade to ignore the possibility of sharp drops in asset prices. See Timothy A. Canova, Financial Market Failure as a Crisis in the Rule of Law: From Market Fundamentalism to a New Keynesian Regulatory Model, 3 HARV. L. \& POL'Y REV. 369, 381-82 (2009) (explaining the introduction of risk-based capital standards). See generally NASSIM NICHOLAS TALEB, THE BLACK SWAN: THE IMPACT OF THE HIGHLY IMPROBABLE (2010) (using a collection of essays, the author explains how improbable events that cause enormous consequences come to fruition and experts do not see them coming).

26. Alberto Alesina \& Lawrence H. Summers, Central Bank Independence and Macroeconomic Performance: Some Comparative Evidence, 25 J. MONEY, CREDIT \& BANKING 151, 160-61 (1993) (focusing on two periods, 1955-1988 and 1973-1988).

27. The 5.4\% figure for the 1941-1951 period was calculated by averaging the annual real GNP growth rates derived from Table B2. See ECONOMIC REPORT OF THE PRESIDENT 204 (1980), https://fraser.stlouisfed.org/docs/publications/ERP/1980/ERP_1980.pdf.

28. See Alesina \& Summers, supra note 26, at 160. 
bank was politically accountable compared to times when it had much greater autonomy. ${ }^{29}$

Some have argued that the 1940s do not present a fair comparison because foreign competitors lost their industrial and export capacities in the wartime destruction. ${ }^{30}$ Such conclusions require overlooking the production miracles of World War II, which would have occurred even if German and Japanese factories were not being destroyed. These critics also define prosperity purely in terms of private consumption. In any event, soon after the war, the United States had a growing current account payments deficit, a result of the combination of costly foreign military commitments and the relatively speedy recovery of Western Europe and Japan, due in large part to the Marshall Plan. The United States extended the post-war boom through the use of active fiscal policies that addressed major social problems. These policies included the huge federal investment in the G.I. Bill of Rights program, providing free higher education, income support, job training, housing, and health care for an entire generation of returning veterans. The benefits were massive in scale because military service was near universal. Mass conscription helped win the war. After the war, this ensured that the number of veterans receiving G.I. Bill support would be massive, as nearly one-third of all U.S. families directly benefitted from the G.I. Bill. The G.I. Bill was based on a view of citizenship in which duties were reciprocal to rights and service was reciprocal to benefits. ${ }^{31}$ Further, the G.I. Bill harmonized capitalism with the idea of a civic republican and communitarian democracy.

Active fiscal policies continued to extend the post-war boom and helped build a huge middle class. From the interstate highway system, the aerospace program, and moon landings, to federal funding for basic research and development, these policies produced long-term universal benefits, incredible technological innovations, and spinoffs for consumers and the private sector. Unfortunately, the orthodox view of

29. Ha-Joon Chang reaches similar conclusions for developing countries, where the period prior to independent central banks was actually the most successful time for developing countries, with per capita income growing by $3.0 \%$ annually in the 1960 s and $1970 \mathrm{~s}$, above the $1.7 \%$ annual growth rates since the $1980 \mathrm{~s}$ after central bank independence and other neoliberal reforms were implemented. See HA-JoON CHANG, BAD Samaritans: The Myth of Free Trade and the Secret History of Capitalism 27 (2008).

30. See generally Robert Higgs, Wartime Prosperity? A Reassessment of the U.S. Economy in the 1940s, 52 J. ECON. HIST. 41 (1992).

31. See Timothy A. Canova, Democracy's Disappearing Duties: The Washington Consensus and the Limits of Citizen Participation, in DEMOCRATIC CITIZENSHIP AND WAR 200, 206-08 (Yoav Peled et al. eds., 2011) (describing the shared benefits of renewed democracy). 
Summer, Bernanke, and others drew all the wrong lessons from the 1940s. They declared fiscal policy a failure and instead claimed that monetary policies alone would sufficiently promote recovery and economic development. Although a more thorough view of history should have demonstrated the folly and danger of such an approach, history was secondary to the calculus of interest group politics and the profit maximization objectives of Wall Street. The Washington Consensus view of citizenship was asymmetrical, a commitment to ever expanding rights and subsidies for the elite and powerful alongside disappearing duties and responsibilities for these same elites.

Mainstream economics has also avoided inquiring into the distributional consequences of central bank capture. However, there is significant empirical, theoretical, and econometric research not associated with the research departments of central banks or Wall Street banks, ${ }^{32}$ which finds positive correlations between central bank independence and growing inequalities in wealth and income. ${ }^{33}$ Heterodox economists have also shown a strong correlation between central bank independence and the pace of financial innovations, including the enormous rise of complex derivative instruments. ${ }^{34}$

Post-Keynesian and Institutional economists emphasize that unregulated financial markets are not self-correcting, that economies often stall at equilibriums far below potential, and that active fiscal policy is perhaps the only path to rebuilding a stable and balanced economy. ${ }^{35}$ As many economists predicted, the consequence of so much

32. See generally BEYOND INFLATION TARGETING: ASSESSING THE IMPACTS AND POLICY ALtERnatives (Gerald A. Epstein \& A. Erinc Yeldan eds., 2009) (compiling theoretical frameworks and country-specific alternatives to inflation targeting).

33. See id. at 8 (explaining the macroeconomic record of inflation targeting); Elissa Braunstein \& James Heintz, The Gendered Political Economy of Inflation Targeting: Assessing its Impacts on Employment, in BEYOND INFLATION TARGETING: ASSESSING THE IMPACTS AND POLICY ALTERNATIVES, id. at 110-12 (concluding that in middle- and lowincome countries dealing with demand-pull inflation, inflation targeting is likely to undermine economic growth); Arjun Jayadev, Income, Class and Preferences Towards Anti-Inflation and Anti-Unemployment Policies, in BEYOND INFLATION TARGETING: ASSESSING THE IMPACTS AND POLICY ALTERNATIVES, $i d$. at 87 (finding systematically differential effects on the welfare of workers compared with owners, and on different segments of the working class). See generally Jose Antonio Cordero, Economic Growth Under Alternative Monetary Regimes: Inflation Targeting vs. Real Exchange Rate Targeting, 22 INT'L REV. APPLIED ECON. 145 (2008) (using econometric analysis to conclude that inflation targeting undermines growth and employment).

34. Gerald Epstein presents econometric evidence correlating independent central banking with more speculative financial markets and lower rates of capacity utilization. See Gerald Epstein, Political Economy and Comparative Central Banking, 24 REv. RADICAL POL. ECON. 1 (1992).

35. See generally Financial Instability AND ECONOMIC SECURITY AFTER THE GREAT RECESSION (Charles J. Whalen ed., 2011) (stressing that, for economies to recover after 
financial innovation and self-regulation was to markedly increase the fragility of the financial system, ${ }^{36}$ resulting in a global financial collapse in the fall of 2008, a phenomenon that the orthodox neoclassical schools of economics did not even see coming.

The myth of central bank independence helps deflect charges of agency capture. Although the Federal Reserve and foreign central banks may be independent of politicians, the question of their independence from private moneyed interests is completely overlooked by the orthodoxy. Mainstream literature considers a number of categories to gauge a particular central bank's degree of political independence, including its legal, goal, operational, and management independence. ${ }^{37}$ But tellingly, no category in the literature analyzes a central bank's relative independence from the private financial interests that play such a significant role in central bank governance.

Although heterodox schools have provided far more coherent diagnoses and prescriptions of financial crises than the orthodoxies, these schools remain marginalized. ${ }^{38}$ What explains the lasting power of the orthodoxy? John Maynard Keynes, the groundbreaking British economist who provided the theoretical justification for active fiscal policy during the Great Depression, once observed, "In economics you cannot convict your opponent of error, you can only convince him of it."39 Economics is not a hard science like physics or chemistry, with predictability and verifiable laws of nature. The subjective and limiting

the Great Recession, nations must evolve their economic thinking, integrate finance with macroeconomics, and pay close attention to expectations).

36. See generally HYMAN P. MINSKY, STABILIZING AN UNSTABLE ECONOMY (2008) (presenting a theoretical explanation of the effect of deregulation on the global economy); Charles P. Kindleberger \& Robert Z. Aliber, Manias, Panics, and Crashes: A HISTORY OF FINANCIAL CRISES (5th ed. 2005) (describing the authors' reservations about deregulation and warning of the impending Great Recession).

37. See J. Ramón Martínez-Resano, Central Bank Financial Independence 7 (Documento Ocasional No. 0401, 2004), available at

http://www.bde.es/f/webbde/SES/Secciones/Publicaciones/PublicacionesSeriadas/Document osOcasionales/04/Fic/do0401e.pdf (outlining the factual categories of institutional freedoms that characterize the degree of central bank independence); Amirul Ahsan et al., Determinants of Central Bank Independence and Governance: Problems and Policy Implications, 1 J. ADMIN. \& GoveRNANCE 47, 50 (2006), http://joaag.com/uploads/4_AhsanSkully_WickramanayakeRevised.pdf (identifying classified subsections of determinants).

38. The liberalization agenda was justified by a variety of pseudo-scientific orthodox economic theories, including rational expectations, real business cycle theory, and the efficient financial market theory-all of which were discredited by the present financial crisis, but live on by force of momentum and career-long commitments in the academy. See ROBERT SKIDELSKY, KEYNES: THE RETURN OF THE MASTER 29-46 (2009).

39. JoHn MaynaRd Keynes, 13 The Collected Writings of JoHn MAYNARd Keynes 470 (Elizabeth Johnson \& Donald Moggridge eds., 1978). 
assumptions of orthodox economic models make these models impossible to disprove. And the entrenched positions of orthodox economists in elite universities and central banks apparently make it impossible to convince them of the flaws in their models.

\section{THE MORAL HaZARD OF AlaAN GREenSPAN}

Alan Greenspan, perhaps more than any other central banker of the past generation, embodied the intersection of the Wall Street and Washington agendas. He had been a director at J.P. Morgan prior to his appointment as Federal Reserve chairman in 1987, and when he stepped down from the Fed in 2006, he landed back on Wall Street, well positioned to take advantage of the impending crash in global financial markets. Greenspan's was a well-worn path, a "revolving door," between the finance industry, elite universities, federal regulators, and central banks. Whatever side of the door, the policy agenda has been the same: the so-called Washington Consensus, also known as neoliberalism or market fundamentalism. ${ }^{40}$ The main pillars of the agenda are the liberalization of trade and finance, deregulation, privatization, central bank independence, and fiscal consolidation.

Central bankers have also referred to their own Jackson Hole Consensus consisting of several key rules of sound economic management, including central bank independence, the primacy of monetary over fiscal policy, and elevating the objective of price stability over employment or income growth.41 Like the related Washington Consensus, this consensus is more related to ideology and faith than to scientific proof. Both of these agendas reflect the interests of private banking constituencies.42 Quite predictably, consensus policies often result in declining incomes and living standards for middle and working class populations, and rising income, wealth, and influence for financial

40. See Joseph E. Stiglitz, Globalization AND Its Discontents 53-54 (2002) (describing the three pillars of Washington Consensus advice). The Washington Consensus has also been referred to as a Washington-Wall Street Consensus, indicating the symbiotic relationship between the two. With shades of Eisenhower's "Military Industrial Complex," Jagdish Bhagwati's reference to a "Wall Street-Treasury-IMF complex" also suggests the influence and capture of federal and multilateral agencies by private financial actors. JAGDISH BHAGWATI, IN DEFENSE OF GLOBALIZATION 205-06 (2004).

41. The Jackson Hole Consensus gets its name from a paper presented at the Federal Reserve's annual economic symposium in Jackson Hole, Wyoming, by Charles Bean, then a top official at the Bank of England. NeIL IRWIN, THE ALCHEMISTS: THREE CENTRAI. BANKERS AND A WORLD ON FIRE 97-98 (2013).

42. BLYTH, supra note 3 , at 156-158 (linking central bank independence to the austerity agenda). 
elites. Even before the crisis, the consensus agenda revealed a bias toward austerity, transforming the United States from an economy based on widely shared prosperity to a winner-take-all society. ${ }^{43}$

Central bank independence, as well as the rest of the consensus agenda, depends on the view that unelected central bankers are more trustworthy stewards of the economy than are elected politicians who may pander to voters. Greenspan, as central-banker-in-chief and the "Maestro," preached a "New Economy" based on deregulation and selfregulation by Wall Street financial institutions. ${ }^{44}$ Arguably, he did more than anyone to deregulate high finance on Wall Street. ${ }^{45}$ Greenspan opened substantial loopholes in the 1933 Glass-Steagall Act, which had separated commercial banking from securities and investment banking. ${ }^{46} \mathrm{He}$ successfully lobbied for its repeal in 1999 with passage of the Gramm-Leach-Bliley Financial Services Modernization Act. ${ }^{7}$ Throughout the $1990 \mathrm{~s}$, he encouraged the growing market in financial derivatives, which are complex financial instruments often used for speculative purposes.

Some legal scholars consider the proliferation of derivatives as the most direct cause of the systemic financial crisis in 2008.48 Traditionally, under English and U.S. common law, courts did not enforce purely speculative derivative contracts in which neither party owned the underlying asset as these were considered gambling contracts. 49 This rule was codified in the Grain Futures Act of 1922 and reenacted during the New Deal as the Commodity Exchange Act (CEA) of $1936 .{ }^{50}$ But things began to change during Greenspan's tenure as Fed chairman. By the early 1990s, Congress allowed the Commodities Futures Trading Commission (CFTC) to exempt privately negotiated over-the-counter (OTC) swaps from regulation and preempt state anti-

43. See generally Robert H. Frank \& PhILIP J. CoOK, The Winner-Take-All Soclety: Why THE FEW AT THE TOP Get So MUCH MORE THAN THE REST OF Us (1996) (outlining the spread of "winner-take-all markets," where small performance differences lead to huge reward differentials).

44. Jacob M. Schlesinger, Did Greenspan Push His Optimism About the New Economy Too Far?, Wall ST. J., Dec. 28, 2001, http://www.wsj.com/articles/SB100949131638223 6920.

45. See Timothy A. Canova, Legacy of the Clinton Bubble, DISSENT, Summer 2008, at 43-47 (discussing Greenspan's laissez-faire philosophy).

46. The Long Demise of Glass-Steagall, PBS FroNTLINe (May 8, 2003), http://www.pbs. $\mathrm{org} / \mathrm{wgbh} / \mathrm{pages} /$ frontline/shows/wallstreet/weill/demise.html.

47. Gramm-Leach-Bliley Act, Pub. L. No. 106-102, 113 Stat. 1338, 12 U.S.C. § 1811 (1999).

48. Lynn A. Stout, Derivatives and the Legal Origin of the 2008 Credit Crisis, 1 HARV.

BUS. L. REV. 1, 3-4 (2011).

49. Id. at 11 .

50. Id. at $12,17$. 
wagering and anti-bucketshop laws. ${ }^{51}$ Although there were plenty of warning signs, Greenspan continued to support a completely deregulated environment. In April 1994, Proctor \& Gamble announced a $\$ 157$ million trading loss from speculating on interest rates through derivatives. A few months later, Orange County, California filed for bankruptcy after more than $\$ 2$ billion in losses on highly leveraged derivatives. ${ }^{52}$ In October 1998, the Long Term Capital Management hedge fund suddenly imploded under the weight of huge trading losses on interest rate and currency derivatives. It took a $\$ 4$ billion industry financed bailout, brokered by the Federal Reserve Bank of New York, to prevent huge losses from further spreading to the biggest banks.

These events did not deter Greenspan and others from beating back an effort by the CFTC, headed by Brooksley Born, to exercise regulatory authority over financial derivatives. ${ }^{53}$ Congress eventually overruled Born and passed the Commodities Futures Modernization Act of 2000 (CFMA) to provide legal cover for OTC derivatives. ${ }^{54}$ Derivatives exploded in volume over the next decade, with over $\$ 50$ trillion in credit default swaps and several hundred trillion dollars in interest rate and currency derivatives.

According to the Financial Crisis Inquiry Commission, created by President Obama to investigate the causes of the 2008 crisis, credit default swaps facilitated the sale of risky and ultimately toxic mortgage related securities, thereby greatly increasing the exposure of the sellers of these swaps to the housing bubble's collapse. ${ }^{55}$ These and other derivatives, such as synthetic collateralized debt obligations (CDOs), enabled speculators to bet against the housing bubble, including Goldman Sachs, which had bet against the same mortgage bonds and CDOs that it had created and already sold off to unsuspecting clients and investors. ${ }^{56}$

Greenspan supported the Bush supply-side tax cuts and provided significant monetary stimulus throughout the early 2000s. He also ignored repeated warnings and requests from the Federal Reserve's Consumer Advisory Council and Fed governor Edward Gramlich to use the Fed's considerable authority under the Home Ownership and Equity Protection Act (HOEPA) of 1994 to investigate and regulate abuses in

51. Id. at $19-20$.

52. Timothy A. Canova, The Transformation of U.S. Banking and Finance: From Regulated Competition to Free-Market Receivership, 60 BRoOK. L. REV. 1295, 1348 (1995).

53. Stout, supra note 48 , at $20,21$.

54. Id. at 21 .

55. Fin. CRISIS INQUIRY COMM'N, The FINANCIAL CRISIS INQUIRY RePORT 155 (2011), http://www.gpo.gov/fdsys/pkg/GPO-FCIC/pdf/GPO-FCIC.pdf.

56. See Michael Lewis, The Big Short: Inside the Doomsday Machine 195-197 (2010). 
the subprime mortgage market.57 Sheila Bair, chair of the Federal Deposit Insurance Corporation (FDIC) from 2006 to 2011, later told the Financial Crisis Inquiry Commission that the authority of the Fed to set mortgage lending rules under HOEPA was the "one bullet" left in the regulatory arsenal that might have prevented the financial crisis. ${ }^{58}$

While Greenspan's regulatory inaction encouraged the growth of risky mortgage securities, federal regulators could have limited the risk to the so-called "Too Big To Fail" banks, including the largest commercial and investment banks, by reducing their leverage and imposing higher capital requirements. The 2004 Basel II capital guidelines, set by the Bank for International Settlements (BIS) Basel Committee on Banking Supervision, called for "risk-weighted" capital standards. ${ }^{59}$ In a coordinated November 2001 rulemaking by four federal regulators, including the Federal Reserve, risk weights were lowered from 50 percent to 20 percent for banks and thrifts on their holdings of triple-A or double-A rated private-label mortgage-backed securities (MBSs). ${ }^{60}$ This rulemaking effectively reduced capital ratios from 4 percent to 1.6 percent for banks purchasing private-label MBS, including those with underlying mortgages consisting of high-risk Option Adjustable Rate Mortgages (ARMs), liar's loans, and subprime loans with low down payments. ${ }^{61}$ In addition, Basel II permitted large commercial banks and bank holding companies to use their own internal risk assessment models to calculate their regulatory capital for their securities portfolios, thereby often reducing their effective capital ratios further. ${ }^{62}$ With the complicity of the major credit rating agencies, banks increased their leverage ratios and stockpiled subprime mortgage bonds.

The Bush administration's Securities and Exchange Commission would eventually follow the Basel II approach to greatly reduce capital standards for the largest investment banks. ${ }^{63}$ This approach permitted

57. Jennifer Taub, Other People's houses: How Decades of Bailouts, Captive Regulators, AND TOXIC BANKers MADE Home MoRTgages a THRILling Business 227 (2014).

58. FIN. CRISIS INQUIRY COMM'N, supra note 55, at 94.

59. TAUB, supra note 57, at 232-33.

60. The other federal regulators that joined the coordinated rulemaking were the Office of Comptroller of the Currency (OCC), Office of Thrift Supervision (OTS), and Federal Deposit Insurance Corporation (FDIC).

61. TAUB, supra note 57 , at 232-33.

62. Internal risk assessment models were first introduced in a 1996 Market Risk Amendment to the Basel Rules. FIN. CRISIS INQUIRY COMM'N, supra note 55, at 151.

63. Id. at 150-54; Timothy A. Canova, George W. Bush and the Failure of LaissezFaire, in THE PRESIDENCY OF GEORGE W. BUSH (forthcoming 2015) (manuscript at 16) (on fle with author). 
these banks to borrow as much as forty dollars for each dollar of capital, leaving them vulnerable to even a small drop in asset prices and increase in funding costs, without the capital to absorb modest, let alone significant losses.64 According to the Financial Crisis Inquiry Commission, this contributed to the "need for government bailouts of all five of the [largest] investment banks during the financial crisis." 65 Bear Stearns and Lehman Brothers closed, Bank of America acquired Merrill Lynch, and Goldman Sachs and Morgan Stanley quickly converted into bank holding companies to gain access to the Fed's discount lending window.

By early 2006, the writing was on the wall. Markets were due for a crash. Goldman Sachs was betting through derivatives against the mortgage market and CDOs that it had created and sold to investors. ${ }^{66}$ In mid-2006, President Bush named Henry Paulson, the CEO of Goldman Sachs, as his new Treasury secretary. This placed Paulson in the perfect position to help his former firm and the rest of Wall Street when the panic hit in 2008. He proposed and crafted the Troubled Asset Relief Program (TARP) authorizing the Treasury to spend up to $\$ 700$ billion to prop up the largest banks. ${ }^{67}$ U.S. banks and thrifts would suffer large losses in late 2008 and into 2009, but thanks to TARP and the Fed's huge liquidity and asset purchase programs, these financial institutions would return to high profit levels a year later. ${ }^{68}$

In 2004, President Bush reappointed Greenspan to a fifth term as Federal Reserve chairman, but Greenspan stepped down in 2006, two years early. His resignation was just in time as he could now return to Wall Street to take advantage of the upcoming crash. He became an advisor to the Pacific Investment Management Company (PIMCO), the world's largest mutual fund, which would make billions in profits on its

64. See generally ANAT ADMATi \& MARTIN Hellwig, THE Bankers' New Clothes: WHAT'S WRONG WITH BANKING AND WHAT TO DO ABOUT IT (2014) (linking the lack of borrowing regulation to resulting effects in the banking industry).

65. FIN. CRISIS INQUIRY COMM'N, supra note 55 , at 155.

66. Greg Gordon, Goldman Executives: We Made Money Betting Against Mortgage Market, MCCLATCHY NEWSPAPERS, Apr. 24, 2010, http://www.mcclatchydc.com/2010/04/ 24/92812/goldman-e-mails-we-made-money.html (reporting that Goldman marketed \$57 billion in risky mortgage securities in 2006 and 2007 without informing investors that it was secretly shorting the housing market).

67. Timothy A. Canova, The Bottom-Up Recovery: A New Deal in Banking and Public Finance, in WHEN Government HELPED: LEARNING FROM THE SuCcesses and FaILURES OF THE NEW DEAL 51, 52-3 (Sheila D. Collins \& Gertrude Schaffner Goldberg eds., 2013).

68. Robin Sidel \& Saabira Chaudhuri, U.S. Bank Profits Near Record Levels, WALL ST. J., Aug. 11, 2014, http://www.wsj.com/articles/u-s-banking-industry-profits-racing-to-nearrecord-levels-1407773976 (including chart of quarterly total net income at U.S. banks and thrifts from 2004 to 2014). 
bond holdings from the Fed's asset purchase programs. ${ }^{69}$ Greenspan also joined the Deutsche Bank's investment banking team and Paulson \& Co., the giant U.S. hedge fund that made billions in profits in 2007 when it bet correctly on the collapse of the subprime mortgage market. ${ }^{70}$

\section{BEN BERNANKE'S MONETARY MYOPIA ON THE GREAT DEPRESSION}

Ben Bernanke auditioned for the job of Federal Reserve chairman while serving as a Fed governor from 2002 to 2005 and as chief of the Bush Administration's Council of Economic Advisers in 2005-2006. In a 2002 speech, he provided assurances that the Fed could prevent any future deflation and depression by simply printing money (or the electronic equivalent) and then making the equivalent of a "helicopter drop" of its newly issued dollars. ${ }^{71}$ As Fed chairman, Bernanke would spend trillions of dollars not on the general population, but instead on the largest financial institutions to ensure their solvency and survival. He rejected all proposals for any "bottom-up" support targeted directly to small and moderate sized businesses, as did the Fed in the 1930s and 1940 s. $^{72}$ Instead, under Bernanke, all Fed support was trickle-down, going solely to Wall Street interests with none going to Main Street. President Obama rewarded "Helicopter Ben" by reappointing him as Fed chairman, and Time magazine named him person of the year for 2009.73

In his academic work on the Great Depression, Bernanke viewed monetary reflation of the banking system as the one, and perhaps sole, effective policy option. He credits President Roosevelt's "bank holiday" in March 1933, the introduction of deposit insurance, and the efforts of the Reconstruction Finance Corporation and Federal Home Loan Banks to prop up creditors. He concludes that it was this financial

69. Carrick Mollenkamp \& Cezary Podkul, Special Report: Pimco Shook Hands with the Fed - and Made a Killing, REUTERS, Sept. 27, 2013, 10:59 AM, available at http://uk.reuters.com/article/2013/09/27/usa-qe3-pimco-idUKL2N0GF11020130927.

70. Angela Monaghan, Greenspan Joins Hedge Fund Paulson, DaILY TELEGRAPH, Jan.

15, 2008, http://www.telegraph.co.uk/finance/newsbysector/banksandfinance/2782593/ Greenspan-joins-hedge-fund-Paulson.html.

71. David Wessel, In Fed We Trust: Ben Bernanke's War on the Great Panic 78 (2009)

72. CANOVA, supra note 4 (manuscript at 12); see generally Canova, supra note 67 (discussing Roosevelt's use of the "bottom-up" approach).

73. Neil Irwin, Obama Picks Bernanke for Second Term as Federal Reserve Chairman, WASH. POST, Aug. 26, 2009, http:/www.washingtonpost.com/wp-dyn/content/article/2009/ 08/25/AR2009082501115.html; Michael Grunwald, Person of the Year 2009: Ben Bernanke, TIME, Dec. 16, 2009, http://content.time.com/time/specials/packages/article/0,28804, 1946375_1947251_1947520,00.html. 
rehabilitation that helped increase employment during the Depression. ${ }^{74}$ This is the trickle-down view that propping up big banks is sufficient to ensure renewed bank lending and new hiring by businesses. As is true with so much of orthodox thinking, the causation may be backward. It ignores the many millions of jobs created directly through New Deal public works and infrastructure projects. As New Deal fiscal policy provided workers, consumers, and debtors with badly needed income, rehabilitation of the banking system could finally be sustained.

Bernanke also suggests that higher real wages in Europe would have been counterproductive during the Depression. ${ }^{75}$ This theory constitutes the austerity view, that rising wages undermines international competitiveness and corporate profits. But the failure of wage austerity under the Bruning government in Weimar Germany led to the rise of Hitler (and ironically, to the Nazi recovery program based on active fiscal policy and massive public works and jobs programs). ${ }^{76}$ Bernanke ignores such lessons and concludes that if monetary accommodation is insufficient to counter deflationary forces, then the solution must be even easier monetary policy in the future. ${ }^{77}$ These views animated Bernanke's approach to the Great Recession of 20072009: when the Fed's first round of quantitative easing (QE) asset purchases proved insufficient to maintain recovery, the only solution was successive new rounds of QE asset purchases.

In his academic work on the Great Depression, Bernanke has overlooked an impressive body of empirical evidence and economic analysis suggesting the crucial role of fiscal policy. The index to Bernanke's Essays on The Great Depression does not even have an entry for fiscal policy. In making the sweeping assertion that rehabilitation of the banking system "was the only major New Deal program that successfully promoted economic recovery,"78 Bernanke's only support is a single footnote that cites to the work of E. Cary Brown, who according to Bernanke, "argued that New Deal fiscal policy was not very

74. Ben S. BERNANKe, ESSAYS ON THE GREAT DEPRESSION 62-63, 253 (2000).

75. Id. at 253 .

76. ChARLES P. KINDLEBERgER, THE WORLD IN DEPRESSION 1929-1939, at 139-40, 153, 174-77 (1973); LYNN TURGEON, STATE AND DISCRIMINATION 20 (1989) (the 10\% wage cut during imposed by the Bruening government resulted in more than $30 \%$ unemployment in Germany); LYNN TURGEON, BASTARD KEYNESIANISM 1-3, 122-123 (1996) (arguing that public works greatly reduced German unemployment in the early 1930s).

77. BERNANKE, supra note 74 , at 7,34 .

78. $I d$. at 63 (emphasizing the monetary factors in the eventual worldwide recovery in output and prices). 
constructive."79 Orthodox Democratic economists, including Christina Romer, ${ }^{80}$ who chaired President Obama's Council of Economic Advisers in 2009-2010, and Larry Summers, ${ }^{81}$ director of Obama's National Economic Council, made many of the same arguments against the efficacy of fiscal policy that were made during the Great Depression. Perhaps such a pessimistic view of fiscal policy has become a prerequisite for an appointment to the Federal Reserve or as a White House economist.

In an article cited by Romer, Summers once again discounted the importance of fiscal policy during the 1940s, arguing that "it is hard to attribute any of the pre-1942 catch-up of the economy to the war." 82 Summers apparently agrees with Bernanke's conclusion that fiscal policy was not the engine of recovery, and subscribes to the idea that monetary policy helped clear the way for a natural recovery, a reversion to the pre-Depression mean. More convincing is the work of J. R. Vernon, who in 1994 concluded, "World War II fiscal policies were the most important factor in the recovery not only during 1942, but during 1941 as well; and more than half of the recovery in output from its 1933 low-point occurred during 1941 and 1942."83 It is difficult to argue with the numbers. In the first six months of the war, the federal government placed over $\$ 100$ billion in war contracts, thereby ordering more goods than the economy had ever produced in a single year. ${ }^{84}$ World War II was the fiscal program that ended the Great Depression once and for all. Yet, in none of his published writings on the Great Depression does Bernanke address or even mention Vernon's work. ${ }^{85}$

79. Id. at 63 n.32. In this footnote, Bernanke also refers to a paper by Michael Weinstein that "points out counterproductive aspects of the N.R.A." Id. However, it is misleading for Bernanke to conflate fiscal policy with the National Recovery Administration. The NRA sought to raise prices by cartelizing industry, an approach that had nothing to do with fiscal policy.

80. See, e.g., Christina D. Romer, What Ended the Great Depression?, 52 J. EcoN. HIST. 757,757 (1992) ("[T] he rapid rates of growth of real output in the mid-and late 1930s were largely due to conventional aggregate-demand stimulus, primarily in the form of monetary expansion.").

81. See, e.g., J. Bradford De Long \& Lawrence H. Summers, How Does Macroeconomic Policy Affect Output?, 2 BROOKINGS PAPERS ON ECON. ACTIVITY 433 (1988) (arguing for the efficacy of monetary policy in post-Depression economic recovery while largely ignoring fiscal policy).

82. Id. at 467 .

83. J.R. Vernon, World War II Fiscal Policies and the End of the Great Depression, 54 J. ECON. HIST. 850, 850-51 (1994).

84. Canova, supra note 31 , at 202.

85. See, e.g., BERNANKE, supra note 74; Ben S. Bernanke, Member, Bd. of Governors of the Fed. Reserve Sys., Money, Gold, and the Great Depression, H. Parker Willis Lecture in Economic Policy at Washington and Lee University (Mar. 2, 2004), available at https:/fraser.stlouisfed.org/docs/historical/bernanke/bernanke_20040302.pdf. 
Perhaps most troubling and revealing is Bernanke's complete mischaracterization of Brown's conclusion that "New Deal fiscal policy was not very constructive." 86 This is a strained and self-serving reading of Brown's work, which in reality suggests the exact opposite of Bernanke's conclusions. ${ }^{87}$ In his influential 1956 article in the American Economic Review, Brown concluded that fiscal policy at all levels of government combined-federal, state, and local-was expansionary in only two years during the 1930 s. $^{88}$ However, Brown also pointed out that the federal government's fiscal position was mostly expansionary throughout the $1930 \mathrm{~s}$, while state and local government fiscal positions were mostly contractionary. ${ }^{89}$ Without the federal New Deal spending, the cumulative impact of state and local austerity would have surely contributed to an ongoing contraction. Instead, federal spending helped cancel out the depressionary effects of state and local austerity. The Depression would have been much longer and more painful for millions of families without the federal government's active fiscal policy and wide reaching New Deal programs that directly employed millions of people and helped reflate aggregate demand and consumer and investor confidence.

In characterizing the federal government's fiscal position as either expansionary or contractionary, Bernanke, Romer, and other mainstream economists treat tax policy no differently than they do changes in government spending. ${ }^{90}$ Brown concluded that the reason fiscal policy was contractionary in the 1930s was "attributable to the sharp increase in tax structures, enacted at all levels of government" with much of the burden on lower- and middle-income groups. ${ }^{91}$ During World War II, taxes rose dramatically on higher-income groups while federal spending rose even faster than did tax revenues. The experience of the 1930s and 1940s provides lessons for the crisis of today by suggesting that a shifting of tax burdens to higher income groups while increasing government spending on infrastructure and jobs programs could lead to a stronger recovery. This experience was also one of the Keynesian lessons, which revealed that redistributing income from the higher income groups to lower income groups through tax and spending

86. BERNANKE, supra note 74 , at 63 n. 32 .

87. E. Cary Brown, Fiscal Policy in the 'Thirties: A Reappraisal, 46 AM. ECON. REV. 857 (1956).

88. Id. at 863 .

89. Id. at 867 .

90. Romer bases her conclusions about the relative expansionary or contractionary effect of fiscal policy on the "ratio of the real federal surplus to real GNP." Romer, supra note 80 , at 762 .

91. Brown, supra note 87 , at $867-68$. 
fiscal policies would likely increase consumer spending and effective aggregate demand.

Bernanke rejects such conclusions: "Absent implausibly large differences in marginal spending propensities among the groups . . . pure redistribution should have no significant macroeconomic effects." 92 In accepting top-heavy distributions of wealth and income, Bernanke's view is a sign of our times. He makes no mention of how a weak economy could alter marginal spending propensities on all income levels, whereby an extra dollar in the hands of a middle- or workingclass family is more likely to be spent on consumption than it is on an extra dollar for those with the highest incomes. ${ }^{93}$ Not surprisingly, Bernanke's approach to the 2008 crisis did not include any strategies designed to redistribute income to debtors as a more direct way to reduce financial distress. To the contrary, the Fed's monetary policies, under both Bernanke and Greenspan, led to greater redistributions of wealth and income from lower and middle income groups to higher income groups.

Brown's most important conclusion, recognized by Romer but completely ignored by Bernanke, is that fiscal policy was not all that successful as a recovery strategy "not because it did not work, but because it was not tried." 94 Tax increases at all levels of government and spending cuts by state and local governments kept the overall fiscal position from playing a significant and sustained expansionary role. The practical lesson should be to cut taxes and/or increase government spending in a weak economy. Instead, Bernanke dismisses the significance of fiscal policy, with the exception of his support for the continuation of the Bush tax rates, which lowered taxes on higher income groups. ${ }^{95}$ Meanwhile, he would have (and did have) the central bank spend trillions of dollars in newly issued money on Wall Street. ${ }^{96}$ For everyone else, there would be austerity and trickle-down fairy tales.

92. BERNANKE, supra note 74 , at 24 (explaining and taking favorably Irving Fisher's debt-deflation theory).

93. Recession also has a way of reducing the velocity of money transactions, thereby deepening the debt-deflation cycle. Bernanke did recognize that wealth redistributions from debt deflations could have aggregate effects when "they are of the form to induce systematic financial distress." Id. at 34 . But his preferred solution to systematic stress is always and only central bank support for creditors and financial markets, which perpetuates the top-heavy distributions.

94. Brown, supra note 87 , at $863-66$.

95. Scott Lanman \& Ryan J. Donmoyer, Bernanke Says Tax-Cut Extension Maintains Stimulus, BloOMBERG BuS., July 23, 2010, http:/www.bloomberg.com/news/articles/201007-23/bernanke-says-extending-bush-tax-cuts-would-maintain-stimulus-to-economy.

96. WESSEL, supra note 71 , at 78 (2009) (bearing the sub-subtitle, "How the Federal Reserve Became the Fourth Branch of Government"). 


\section{AUSTERITY AND THE FEDERAL RESERVE'S “TRICKLE-DOWN" MONETARY POLICY}

The Federal Reserve serves as "lender of last resort," lending directly to commercial banks through its so-called discount lending window. ${ }^{97}$ Traditionally, only commercial banks had access to the Fed's discount lending since non-bank financial institutions were not subject to the same reserve and capital requirements imposed on banks. The other major source of the Fed's power is its ability to purchase financial assets from its primary bond dealers. The Fed's asset purchases were traditionally limited to short-term Treasury securities. ${ }^{98}$ These restrictions on Fed lending and asset purchases helped support the central bank's political independence from Congress and the White House by ensuring that Fed policy was socially neutral and did not favor particular sections of financial markets or particular private constituencies. But, as the Federal Reserve's lending and asset purchase powers expanded in unprecedented ways under Ben Bernanke in 2008, these traditional restrictions were swept aside, exposing the flaws of central bank independence.

The Fed also creates money-U.S. dollars, also known as Federal Reserve Notes-which means there is virtually no limit to the amount of money it can lend and no limit to the volume of assets it can purchase without adding to public sector borrowing or deficits. During the 20082009 financial crisis, the Fed extended more than $\$ 16$ trillion in low interest loans to all kinds of financial institutions in distress, including borrowers who traditionally lacked access to its discount window, such as hedge funds and foreign commercial banks and central banks. ${ }^{99}$ Also, beginning in 2008, the Fed launched several asset purchase programs, known as Quantitative Easing or QE, to purchase more than $\$ 3.5$

97. Depository institutions that are short on reserves can borrow short-term from other banks in the overnight lending market. The rate charged on such loans is known as the federal funds rate. Banks can also borrow directly from the Fed's discount window at the discount rate set by each of the Fed's regional Reserve Banks, subject to the approval of the Board of Governors. See id. at 27-50.

98. Timothy A. Canova, Who Runs the Fed?, 62 Dissent 126, 126 (2015). In the 1990s, nearly $60 \%$ of the Fed's holdings were in the form of Treasury bills (with maturities of one year or less) and about a quarter in Treasury notes (with maturities of over one year and less than five years). BD. OF Governors of THE FED. Reserve Sys., The Federal RESERVE SYSTEM: PURPOSES AND FunCTIONS 37 (8th ed., 1994). By 2006, the Fed's holdings had shifted somewhat, with nearly half in Treasury bills and about a third in Treasury notes. Not much of the Fed's portfolio was in longer Treasury maturities. See BD. OF GOVERNORS OF THE FED. RESERVE SYS., 93RD ANNUAL REPORT 2006, at 329 (2006), available at http://www.federalreserve.gov/boarddocs/ rptcongress/annual06/pdf/ar06.pdf.

99. Press Release, Bernie Sanders, U.S. Senator for Vt., The Fed Audit (July 21, 2011), available at http://www.sanders.senate.gov/newsroom/press-releases/the-fed-audit. 
trillion in U.S. Treasury securities and MBSs. ${ }^{100}$ But this expansion of the money supply is deceiving. Instead of lending out the funds supplied by the Fed, banks have added almost $\$ 3$ trillion to their excess reserves and the Fed has paid them interest on those reserves. ${ }^{101}$ This is similar to what happened during the Great Depression. ${ }^{102}$ Much of the money the Fed pushed into the banking system has not trickled down to the real economy.

Bernanke, the Fed chairman when the QE programs were first launched, claimed that asset purchases would have a "wealth effect"103: by the Fed purchasing bonds in such large amounts, bond prices would rise, yields would fall, and investors would shift into riskier securities, driving up the price of corporate shares and stock markets. ${ }^{104}$ Everyone would feel richer, businesses would invest, and consumers would spend more. This seems similar to the theory of "trickle-down" fiscal policy: that tax cuts for those with high incomes would be invested, thereby leading to the hiring of additional workers and spreading the benefits to the rest of the economy. Like the Bush administration's tax cuts, the Fed's monetary trickle-down also has not worked. The lending and asset purchase programs have effectively propped up Wall Street interestsbig banks and financial markets-but they have also neglected the needs of Main Street, including the small community banks, small and moderate sized and family-owned businesses, unemployed and underemployed workers, and state and local governments.

The Federal Reserve's response to the 2008 crisis is quite different from its "bottom up" approach in the Great Depression in the 1930s when it extended credit directly to Main Street businesses. Section 13(3)

100. Mard Labonte, Cong. Research Serv., R42962, Federal RESERve: UNCONVENTTONAL MONETARY POLICY OPTIONS 3 (2014), available at http://fas.org/sgp/crs/misc/R42962.pdf; see Christopher Rude, The Role of the Federal Reserve: Lender of Last Resort, in THE HANDBOOK OF THE PoltTiCal ECONOMY OF FinANCIAL CRISES 602, 605-8 (Martin H. Wolfson \& Gerald A. Epstein eds., 2013) (detailing the Federal Reserve's response to the financial crisis, including quantitative easing).

101. Mary Anastasia O'Grady, Political Diary: Federal Reserve Excess, WALL ST. J., Oct. 23, 2013, http://www.wsj.com/articles/SB10001424052702304069604579153290395722608.

102. See Milton Friedman \& ANNA JaCoBson SchWARTZ, A MONETARY HISTORY OF THE UNITED STATES 1867-1960, at 449-62 (1963) (discussing the policies of private banks during the Depression).

103. Ben S. Bernanke, Aiding the Economy: What the Fed did and why, WASH. PoST, Nov. 4, 2010, http://www.washingtonpost.com/wp-dyn/content/article/2010/11/03/AR20 10110307693.html (arguing that the Fed's asset purchases would increase stock prices and thereby "boost consumer wealth" and economic expansion).

104. See Richard A. WeRner, PRINCES of the Yen: JaPAN's CEntral Bankers and the TRANSFORMATION OF THE ECONOMY 256, 326-27 n.75 (2003) (discussing the effect of bond purchases by central banks). 
of the Federal Reserve Act allowed the Fed to lend directly, not just to big banks, but also to "individuals, partnerships, and corporations" in "unusual and exigent circumstances." 105 Another provision, section 13(b), authorized the Fed to make credit available for "working capital to established industrial and commercial businesses" with permissible maturities of up to five years and "without any limitations as to the type of security" for collateral. ${ }^{106}$ In total, the Fed made about $\$ 280$ million available to small and moderate sized businesses. That was about 0.43 percent of GDP at the time, or about $\$ 65$ billion today. ${ }^{107}$

In contrast, in the aftermath of the 2008 financial panic, the Federal Reserve has consistently rejected proposals to lend directly to Main Street, including proposals for loans to state infrastructure banks; to Fannie Mae and Freddie Mac (two government supported entities that hold trillions of dollars in mortgages) to modify underwater mortgages; and to students to refinance their debts. Throughout this time, Fed officials adopted the view that they lack the legal authority for such lending and, in particular, that federal law requires there be "good collateral" for any such loans. 108

However, such requirements did not stop the Federal Reserve from lending $\$ 29$ billion to J.P. Morgan Chase to purchase Bear Stearns in March 2008, secured only by Bearn Stearns' shaky mortgage-related assets. ${ }^{109}$ This move led Paul Volcker, a former Fed chairman, to express concern that the Fed's intervention was testing the limits of its lawful powers and would call into question the Fed's political independence if the central bank was viewed "as the rescuer or supporter of a particular section of the market," such as mortgage-backed securities,

105. Federal Reserve Act $\S 13,12$ U.S.C. $\S 343$ (2006), amended by Dodd-Frank Act of 2010, Pub. L. No. 111-203, Title XI, § 1101(a), 124 Stat. 2113 (current version at Federal Reserve Act $\S 13(3), 12$ U.S.C.S. $\$ 343($ A) (LexisNexis 2015)); see Canova, supra note 67.

106. Act of June 19, 1934, Pub. L. No. 73-417, 48 Stat. 1108, repealed by Small Business Investment Act of 1958, Pub. L. No. 85-699, 72 Stat. 690; David Fettig, Lender of More Than Last Resort, THE REGION, Dec. 2002, at 15, 19, available at https://www. minneapolisfed.org/ /media/files/pubs/region/02-12/lender.pdf.

107. Fettig, supra note 106, at 45.

108. Ben S. Bernanke, Chairman, Bd. of Governors of the Fed. Reserve Sys., Federal Reserve Response to the Financial Crisis: Hearing Before the H. Comm. on Fin. Serv., 111th Cong. (2009), available at http://www.federalreserve.gov/newsevents/testimony/ bernanke20090210a.htm.

109. Ben S. Bernanke, The Federal Reserve and the Financial Crisis 77 (2013); see also id. The Fed's $\$ 16$ trillion lending program was not without its rationalizers who argued for interpreting the Bagehot rule as lending freely "against collateral that will be good in the long run (even if it is not good today)." Willem H. Buiter, Prof. of Eur. Pol. Econ., Central Banks and Financial Crises, Presentation at the Federal Reserve Bank of Kansas City Symposium: Maintaining Stability in a Changing Financial System (Aug. 23, 2008), available at $\mathrm{http} / / / \mathrm{www} . k a n s a s c i t y f e d . o r g /$ publicat/sympos/2008/Buiter.03.12.09.pdf. 
collateralized debt obligations (CDOs), and other exotic financial instruments. 110 Volcker warned that such allocation decisions are inherently political, "not strictly a monetary function in the way it's been interpreted in the past," and are more properly made by the elected branches of government as fiscal policy. ${ }^{111}$ Yet, throughout 2008-2009, the Fed expanded its lending well beyond its traditional statutory authority, including to primary dealers in U.S. Treasury securities and foreign exchange swap lines for foreign central banks. ${ }^{112}$ The Fed also lent more than $\$ 700$ billion to a facility of its own creation, a "special purpose entity," to purchase commercial paper directly from major corporate borrowers, which helped support big businesses and cartels, while ignoring the small and moderate sized and family enterprises that give life to Main Streets across the country. ${ }^{113}$ It was clear that the courts and political branches of government would not interfere with the Fed's determination of what constitutes good collateral and the scope of its lawful powers in "unusual and exigent circumstances," particularly when helping Wall Street in a crisis.

The Federal Reserve expanded its support for Wall Street in other unconventional ways that also suggested a bias in favor of the private financial interests that sit on the Fed's own governing boards. In the fall of 2008, the Fed made an emergency equity investment in American International Group (AIG), taking a 79.9 percent interest in the global insurance conglomerate, to make sure that AIG continued paying off on its credit default swaps (CDS) to Goldman Sachs and other counterparties. 114 These swaps provided insurance against a downturn in the housing and mortgage markets. However, swaps also allowed Goldman Sachs and other speculators to bet against the same toxic mortgage-backed securities that they had created and already sold off to unsuspecting clients and investors. By rescuing AIG, an extraordinary measure that tested the limits of its authority, the Fed was now the "buyer, dealer, and gambler of last resort," serving as the gambling house to prop up the market for derivative contracts and cover the wagers and losses of the global casino. 115

Goldman Sachs and other giant banks and hedge funds have engaged in similar shady and speculative activities abroad, including

110. Greg Ip, Fed Balance Sheet Worries Volcker, WALL ST. J., May 15, 2008, at A3.

111. Id.

112. Rude, supra note 100 , at 607 .

113. Id.

114. See generally LEWIS, supra note 56 (discussing a motive for the Fed's emergency equity investment in AIG).

115. See generally Perry Mehrling, The New Lombard Street: How the Fed BECAME THE DEALER OF LAST RESORT (2011) (tracing the evolution of ideas and institutions in the U.S. banking system). 
betting on Greek, Spanish, and Italian sovereign and private debt. Through the use of derivatives, Goldman Sachs shorted the same Greek debt that it previously aided the Greek government in hiding through repo transactions. 116 The response of the ECB and IMF assured that these speculators' bets would be paid off. Along with JP Morgan Chase and other big banks, Goldman Sachs would then take advantage of the austerity imposed on Greece and other countries by setting up infrastructure funds to buy up state-owned assets in fire-sale privatizations. ${ }^{117}$

Unlike the Federal Reserve's lending programs, which have at least a semblance of statutory guidelines, the Fed has more discretion in its asset purchase programs, which have provided a longer lasting effort at trickle-down monetary policy. In the first $\mathrm{QE}$ program, which began in November 2008, the Fed purchased $\$ 1.25$ trillion in MBS, $\$ 300$ billion in Treasury securities, and $\$ 200$ billion in Fannie Mae and Freddie Mac "agency debt," all with money newly created by the Fed.118 The Fed was no longer just taking distressed mortgage bonds as collateral on loans, which had been Volcker's concern, it was now actually purchasing more than a trillion dollars in these assets.

When this QE program ended, the U.S. economy once again slowed. The financial markets became addicted to the Fed's massive bond purchases, and when each QE ended the markets needed another fix. ${ }^{119}$ The Fed responded in November 2010 with QE2 to purchase an additional $\$ 600$ billion in Treasury securities. Next came "Operation Twist" a year later, in which the Fed shifted some of its portfolio of

116. See John Carney, Goldman Sachs Shorted Greek Debt After It Arranged Those Shady Swaps, BUS. INSIDER (Feb. 15, 2010, 9:40 AM), http://www.businessinsider.com/ goldman-sachs-shorted-greek-debt-after-it-arranged-those-shady-swaps-2010-2 ("Despite its role in creating swaps that may have allowed the Greek government to mask its growing debts, Goldman has no net exposure to a default on Greek debt.").

117. See Jenny Anderson, Cities Debate Privatizing Public Infrastructure, N.Y. TIMES, Aug. 26, 2008, http://www.nytimes.com/2008/08/27/business/27fund.html?pagewanted=all \&_r=0 (reporting that Goldman Sachs, Morgan Stanley, and the Carlyle Group "are among the investors who have amassed an estimated $\$ 250$ billion war chest" to buy up infrastructure projects in privatization sales); Seumas Milne, The Tide is Turning Against the Scam that is Privatisation, THE GUARDIAN, July 9, 2014, http:/www.theguardian.com/ commentisfree/2014/jul/09/tide-turning-against privatisation?CMP =share_btn_tw; Jerin Mathew, Goldman Sachs Plans to Launch Infrastructure Fund, INT'L BUS. TIMES, Oct. 3, 2014, 10:56 AM, http://www.ibtimes.co.uk/goldman-sachs-plans-launch-infrastructurefund-1468357; Michael Nevradakis, Greg Palast: Greece is a Crime Scene, and Vulture Funds Are to Blame, TRUTHOUT (Jan. 9, 2015, 10:20 AM), http://www.truth-out.org/news/ item/28446-greg-palast-greece-is-a-crime-scene-and-vulture-funds-are-to-blame.

118. LABONTE, supra note 100, at 3 n.6 ("Agency securities and MBS are primarily issued by Fannie Mae and Freddie Mac, with some securities issued by the Federal Home Loan Banks and Ginnie Mae.").

119. Rude, supra note 100 , at 607 . 
Treasury securities from short-term to long-term maturities, intended to bring down long-term interest rates on other securities and mortgage loans. ${ }^{120}$ Finally, in September 2012, the Fed announced QE3, an openended pledge to purchase $\$ 40$ billion of agency MBS and $\$ 45$ billion of long-term Treasury securities each month. ${ }^{121} \mathrm{QE3}$ continued for nearly two years.

Critics have charged the $Q E$ approach with pumping up financial markets and Wall Street banks, creating new bubbles, ignoring the needs of real people and Main Street businesses, and weakening the currencies of countries following the approach, thereby impairing growth in other nations. ${ }^{122}$ After several years and trillions of dollars in Federal Reserve asset purchases, the U.S. stock market and Manhattan real estate prices reached new heights, and more than 90 percent of income gains flowed to the top 1 percent of households. ${ }^{123}$ Yet, the Fed's $\mathrm{QE}$ programs became the model for other major central banks. Beginning in March 2009, the Bank of England purchased about $\$ 569$ billion in assets, in at least three rounds, increasing the total each time the effect of the previous round wore off. ${ }^{24}$ As the Fed was tapering off its QE3 purchases, the Bank of Japan launched its own QE program of $\$ 1.4$ trillion in asset purchases. ${ }^{125}$ More recently, the ECB announced its QE program of $\$ 69$ billion a month in public and private bond purchases, to total more than $\$ 1.3$ trillion. ${ }^{126}$ This soon resulted in its own kind of austerity by pushing down the value of foreign currencies

\footnotetext{
120. Id.

121. David Wessel, For Fed, Risks of Goosing Market are Worth It, WALL ST. J., Oct.14, 2010, http://www.wsj.com/articles/SB10001424052748704763904575550090298620152 8704763904575550090298620152 (reporting that Quantitative Easing is "when the Fed turns up its electronic printing presses" and creates money to purchase financial assets).

122. Richard Blackden, Brazil President Dilma Rousseff Blasts Western QE as 'Monetary Tsunami', THE TELEGRAPH, Apr. 10, 2012, http://www.telegraph.co.uk/finance/economics/ 9196089/Brazil-president-Dilma-Rousseff-blasts-Western-QE-as-monetary-tsunami.html (criticizing the QE programs for weakening currencies of developed countries, thereby impairing growth in other nations).

123. Josh Barro, 95\% Of Income Gains Since 2009 Went To The Top 1\% - Here's What That Really Means, BUS. INSIDER (Sept. 12, 2013, 1:20 PM), http://www.businessinsider. com/95-of-income-gains-since-2009-went-to-the-top-1-heres-what-that-really-means-2013-9.

124. Katie Allen, Quantitative Easing Around the World: Lessons from Japan, UK and US, THE GUARDIAN, Jan. 22, 2015, http://www.theguardian.com/business/2015/jan/22/ quantitative-easing-around-the-world-lessons-from-japan-uk-and-us (comparing the UK's QE program (375 billion pounds, or $\$ 569$ billion) with Japan's (\$1.4 trillion)).

125. Id.

126. David Goodman, Euro Weakens as Draghi Announces Expanded Asset-Purchase Program, BLOOMBERG BUS., Jan. 22, 2015, 9:55 AM, http://www.bloomberg.com/news/ 2015-01-21/euro-pares-gains-as-ecb-to-propose-50-billion-a-month-in-qe.html (reporting the size of ECB QE program as being more than $\$ 69$ billion a month in public and private bond purchases, totaling $\$ 1.3$ trillion).
} 
and strengthening the dollar, thereby weakening U.S. exports and slowing the already weak U.S. economic recovery.

In helping Wall Street and global capital markets, the Fed stretched its asset purchasing well beyond its traditional powers. Meanwhile, the Fed claimed a lack of authority to help Main Street interests, even on a far lesser scale. For example, some on the right have proposed that the Fed purchase state and municipal bonds to help finance new infrastructure like construction and repair of roads and bridges. ${ }^{127}$ Proposals from the left call for the Fed to pump money into state infrastructure banks and to purchase student debt to allow moratoriums on debt repayment while labor markets remain weak. Others urged the Fed and ECB to make cash transfers directly to consumers and taxpayers. ${ }^{128}$ From both sides of the spectrum came proposals for mortgage loan modifications, financed either directly by the Fed or by the Treasury with Fed support. ${ }^{129}$ These kinds of QEs for Main Street, like the Fed's QEs for Wall Street, would incur no costs to government, would not add to deficits, and would put tax-paying resources back to work. Such monetary policies would have prodded the United States and Eurozone away from austerity and perhaps deflation, and instead pushed them in the direction of a more heterodox and Keynesian full-employment political economy.

\section{CONCLUSION}

Federal Reserve governance and independence is often defended as a corporatist structure that allows the Fed to draw on the expertise of bankers and financiers. ${ }^{130}$ But the exclusion of all social groups, other

127. See generally Joseph A. Grundfest et al, Op-Ed., Getting More Bang for the Fed's Buck, N.Y. TIMES, Oct. 24, 2012, at A25 (discussing proposals relating to the right of the Federal Reserve to purchase state and municipal bonds).

128. See WERnER, supra note 104, at 273; Mark Blyth \& Erik Lonergan, Print Less but Transfer More: Why Central Banks Should Give Money Directly to the People, ForEIGN AFFAIRS, Sept./Oct. 2014, http:/www.foreignaffairs.com/articles/141847/mark-blyth-anderic-lonergan/print-less-but-transfer-more. John Muellbauer, a senior fellow at Oxford University's Institute for New Economic Thinking, has called on the European Central Bank to print money and give five hundred euros to every person in the Eurozone. Jack Ewing, Eurozone Takes on Quantitative Easing, and Its Risks, N.Y. TIMES, Jan. 29, 2015, http://www.nytimes.com/2015/01/30/business/international/eurozone-takes-on-

quantitative-easing-and-its-risks.html.

129. Vernon L. Smith, Vernon Smith: Disequilibrium in the Housing Market, NewSWEEK, Jan. 23, 2011, 8:00 PM, http://www.newsweek.com/vernon-smithdisequilibrium-housing-market-66953.

130. José Gabilondo, Financial Hospitals: Defending the Fed's Role as a Market Maker of Last Resort, 36 SEATTLE U. L. REV. 731, 790 (2013) (discussing the governance structure of the Federal Reserve). 
than bankers, from Fed governance is quite different from the kind of corporatism that served the United States so well during the "golden age" of capitalism from the 1940s to the 1970s, when labor had a seat at the table to provide a "counterveiling power" to big business and banking interests. ${ }^{131}$ Scholars of corporatism recognize two corporatisms at opposing ends of the spectrum. At one end, the corporatism of fascist regimes delegates public power to private sector governments dominated by elite interests in ways that exclude and often crush labor organizations. At the opposing end, a social democratic corporatism includes labor interests in the decision process. ${ }^{132}$ By excluding a broad range of social interests that are often negatively affected by Fed policy decisions, the regional Feds and the FOMC are far from the social democratic end of the corporatist spectrum.

The irony is that central bank independence and the austerity that it promotes has had a devastating effect throughout the Eurozone, contributing to enormously high levels of unemployment, and thereby encouraging the growth of fascist parties on the right. In assessing the Fed's responses to the crisis, Neil Irwin concluded that public pressure on the Fed was mostly one sided: "Many conservatives and financial market commentators assailed the central bank for its easy money stance, and there was little in the way of a crusade from the left to try to encourage greater activism by the Fed." ${ }^{133}$ On the mainstream left, Paul Krugman suggested more monetary trickle-down throughout 2010, that the Fed might need even larger QE programs, perhaps as much as $\$ 8$ trillion to $\$ 10$ trillion in bond purchases, to engineer a full economic recovery. ${ }^{134}$ Although Fed purchases of Treasuries and mortgage bonds proved less than effective, Krugman's solution was to have the central bank simply purchase a lot more of the same assets.

Bernanke's success came from straddling the intersection between New Classical and New Keynesian economics. As Alan Blinder points

131. Id. at $791, \mathrm{nn} .420-421$.

132. Peter Kriesler \& Joseph Halevi, Corporatism in Australia, 1-8, 14-16 (Univ. of New S. Wales Social Policy Research Ctr., Discussion Paper No. 57, 1995) (exploring a form of corporatism that delegates public power to the private sector); President Kennedy's attempt to fashion a wage and price accord for the strategically important steel industry may be seen as an example of a social democratic corporatism that included the countervailing powers of business, labor, and government. GIBSON, supra note 9, at 6, 918; Videotape: Kennedy Calls Out the Steel Companies (1962), YoUTUBE (Oct. 12, 2010), https://www.youtube.com/ watch?v=zWNhWANkq0Q.

133. Neil Irwin, The Depression's Unheeded Lessons, N.Y. TIMES, Jan. 10, 2015, http://www.nytimes.com/2015/01/11/upshot/the-depressions-unheeded-lessons-.html?abt= $0002 \& \mathrm{abg}=0$.

134. See Videotape: Paul Krugman's Newest QE2 Fantasy, THE DAILY BAIL (Oct. 13, 2010), http://dailybail.com/home/paul-krugmans-newest-qe2-fantasy-video.html (reproducing original interview with Krugman). 
out, most American Keynesians, including Bernanke, "have long believed that expansionary monetary policy is a better way to fight recessions than expansionary fiscal policy."135 The monetary orthodoxy continues under Fed chair Janet Yellen, Bernanke's successor who is supposedly more Keynesian, but it is the New Keynesianism that is all too comfortable with fiscal austerity and high levels of unemployment.

Keynes suggested that in economics you cannot convict your opponent of error. He perhaps naively believed that orthodox thinkers could be convinced based on evidence, the power of persuasion, and the merits of argument. Krugman described the New Classical repression within the academy, which marginalizes and punishes those who question the orthodoxy by withholding jobs and publishing opportunities in major journals. Unfortunately, much of the same dynamic occurs in the academy, halls of government, and central banking among New Keynesians and their own orthodoxies of endless quantitative easing programs. As seen in Inside Job, the 2010 Academy Award winning documentary on the financial crisis, even elite scholars and economists enjoy tremendous "revolving door" benefits by currying favor with Wall Street interests. ${ }^{136}$ Perhaps it is not possible to convince orthodox economists of the errors in their thinking when high salaries and elite positions depend on not being convinced. ${ }^{137}$ Jurists, legislators, and legal scholars have largely deferred to economic elites on questions of central bank independence and austerity policies. But a rigged governance process inevitably leads to rigged outcomes. The longer reform of central bank governance is delayed, the longer we will have to live with trickle down monetary and fiscal policies that contribute to enormous inequalities in income, wealth, and power.

135. Alan S. Blinder, After the Music Stopped: The Financlal Crisis, the RESPONSE, AND THE WORK AHEAD 350 (2013). According to Bernanke and other New Classical economists' view, when expansionary fiscal policy is used, it should take the form of tax incentives, rather than public works and jobs programs. Id. at 350 .

136. INSIDE JoB (Sony Pictures 2010).

137. Upton Sinclair made this point long ago: "It is difficult to get a man to understand something, when his salary depends on his not understanding it." UPTON SINCLAIR, I, CANDIDATE FOR GOVERNOR: AND HOW I GOT LICKED 109 (1994). 